\author{
Research Article \\ (c) 2020 Mery Kusuma Dewi and Dewi Tamara. \\ This is an open access article licensed under the Creative Commons \\ Attribution-NonCommercial 4.o International License \\ (https://creativecommons.org/licenses/by-nc/4.o/)
}

\title{
The Intention to Invest in Retail Bonds in Indonesia
}

\author{
Mery Kusuma Dewi \\ Dewi Tamara \\ Magister Manajemen BINUS Business School, \\ Universitas Bina Nusantara, Senayan, \\ Kebayoran Baru, Jakarta Selatan, \\ DKI Jakarta, Indonesia
}

DOI: https://doi.org/10.36941/ajis-2020-0097

\begin{abstract}
The low rate of investment in retail bonds among state-owned enterprise employees is worrying because this product is aimed at this type of customer. The theory of planned behaviour explains the possible reason(s) why the employee is reluctant to invest in retail bonds. This study sheds light by adding the product involvement variable to the original model to identify the intention to spend and what the factors are those are influencing it. As predicted, attitude and subjective norm are positively related to the intention to invest in retail bonds. Based on the results of data processing, it was found that the attitude and subjective norm variables are factors that positively and significantly affect the intentions of ORI investment by IDX employees. Also, the results of data processing showed that intention had a significant effect on the investment behaviour of ORI by IDX employees. This study is limited to discussing the intentions of ORI investment by IDX employees, making it possible for other researchers to examine different variables.
\end{abstract}

Keywords: Intention to Invest, Planned Behavior, Retail Bonds, Product Involvement

\section{Introduction}

In the past ten years, retail government bond (ORI) transactions in Indonesia showed a rising trend in demand from domestic retail investors, and the coupon rate was also higher. ORIoo7 was issued in 2010 and was due in 2013 with a coupon rate of $7.95 \%$ per annum. ORIo15 was released on 18 October 2018 and is due in 2021 with a coupon rate of $8.25 \%$ per annum. The number of investors increased from 17,705 to 41,306 accounts. The subscription rate also increased, from Rp 8 million to Rp 23 million.

A joint effort from the Ministry of Finance of the Republic of Indonesia, Bank Indonesia, the Financial Services Authority, the Indonesia Stock Exchange (IDX), the Indonesian Securities Clearing Guarantee (KPEI) and the Indonesian Central Securities Depository (KSEI) showed the results of improving financial inclusion and literacy.

The objective of this paper is to investigate the investment intention of the employees of the Indonesia Stock Exchange (IDX). The total number of employees at the exchange was 500, which represented a substantial pool of new investors. However, based on a pilot interview with thirteen IDX employees, only three people chose to invest in ORI. Others preferred time deposits, savings and mutual funds. The employees of IDX were prohibited from owning and conducting transactions on 
shares and derivatives including stock option contracts, stock futures contracts, stock index futures, pre-emptive rights and warrants (PT BEI Code of Conduct version 2, May 2019).

To investigate the intention of investing, we used the Theory of Planned Behaviour (Ajzen, 1991). The intention to do something is triggered by attitude, subjective norm and perceived behavioural control. This paper used the Theory of Planned Behaviour (TPB) to explain the phenomenon about intention to save and invest (Kobbeltvedt \& Wolff, 2009; Aleyne \& Broome, 2011; Cuccinelli, Gandolfi, \& Soana, 2016; Satsios \& Hadjidakis, 2018) among others.

The contributions of the study regarding the intention to invest were multiple. First, we added a new variable called product involvement to the original model, since the object was a retail obligation, it was essential to investigate the attributes of bonds. Second, we used an extensive database of employees of IDX to identify their behaviour towards bonds. Third, the study was the first to locate the intention to invest retail bonds as investment choices for employees.

\section{Literature Review}

Ajzen (1991, 2005) explained that 'attitude' or 'attitude towards behaviour' is determined by beliefs about the consequences of behaviour called 'behavioural expectations'. Two antecedents influence behavioural expectation: the behaviour of belief and outcome evaluation. Confidence relates to an individual's subjective assessment of the world around them, an individual's understanding of themself and their environment which were carried out by linking certain behaviours with various benefits or losses that might be obtained if the individual did or did not perform an action. This belief could strengthen attitudes toward the behaviour if based on evaluations conducted by individuals, with data that the behaviour could provide benefits for them. For example, if someone considers something useful for himself, then they will give a positive response to it, on the contrary, if something is not helpful, then they will provide a negative response. The outcome evaluation is a result of one's assessment of behaviour.

Cucinelli et al. (2016) found that attitude had a positive and significant impact on intention in applying for financial products in Italy. Gopi and Ramayah (2007) found that attitude, subjective norms and perceived behavioural control were factors that had a positive influence on the intention to invest in online shares in Malaysia.

A subjective norm is a social factor that relates to the perceived social pressure for an individual to perform or not to perform one's behaviours (Ajzen, 1991). In some communities, the subjective norm is influenced by a normative belief and motivation to comply. The normative view is an opinion of an agreement and/or disapproval of a person, figure, role model, or group that is considered necessary to a behaviour. A motivation to comply implies how far individuals will follow to comply with these opinions.

Subjective norms about behaviours will be high if the normative beliefs and motivations to meet the expectations of vertically related people are equally high. For horizontal relationships, subjective norms will be high if the individual's knowledge in other individuals is firm (Ajzen, 2005).

For an employee of IDX, the subjective norm to invest was a limit to the code of conduct. These rules stated that employees could not invest in stock and its derivatives such as options contracts, stock futures contracts, stock index futures, pre-emptive rights and warrants (IDX Code of Conduct version 2, May 2019). The code of conduct avoids conflicts of interest and maintains the credibility of the company. Regarding the intention to invest, the employee should choose other investment products outside those prohibited by the code of conduct. The management led the investment intention to retail bonds (ORI) and encouraged them to invest there.

Alleyne and Broome (2011) found that subjective norms were the most critical factors that significantly influenced investment intentions. Opinions and suggestion from peer are crucial for investment product decision-making. Furthermore, Sondari and Sudarsono (2015) stated that subjective norms had a significant influence on the intention to invest among civil servants.

Ajzen (2005) described perceived behavioural control as an original idea about supporting 
factors and obstacles to performing a behaviour (or salient control beliefs). Perceived behavioural control is based on an individual's previous experience, knowledge, and feelings about performing the activity. Specifically, in TPB, perceived behavioural control is defined as an individual's perception of the ease or pain of performing a behaviour. Perceived behavioural control is determined by a combination of individual beliefs about supporting factors and inhibitors to conduct a behaviour (control beliefs), with the strength of personal feelings about each promoting or inhibiting factor (perceived power control). In general, the more individuals feel a lot of supporting factors and fewer inhibiting factors the more likely they are to be able to perform a behaviour. Individuals will tend to perceive it easy to do the action or vice versa; the more individuals feel fewer supporting factors and many inhibiting factors to more likely they are to be able to make a response. The individual will tend to perceive themselves as challenged to do the practice (Ajzen, 2005).

TPB-related research conducted by Satsios and Hadjidakis (2018) showed that perceived behavioural control had a positive effect on saving intentions. Other research conducted by Ali, Zani and Kasim (2014), showed that attitude and perceived behavioural control had a significant and positive influence on investor intentions to invest in Islamic unit trusts. Research conducted by Octarina, Hartoyo and Beik (2019) found that although attitude and subjective norm had a positive and significant effect, the perceived behavioural control variable did not influence the intention to invest in Sharia mutual fund products.

According to Zaichkowsky (1985), product involvement was a significant factor in explaining why consumers chose certain products. Theoretically, a product falls into high or low involvement categories (Zaichkowsky, 1985). If a product was high involvement, consumers would be involved in more active information seeking and would examine various more significant alternatives in their decision-making (Kwon, Lee, \& Jin Kwon, 2008). Ibrahim and Arshad (2017) found a meaningful relationship between product involvement and stock investment intentions carried out by individual investors in Pakistan.

Ajzen (1991) explained that intention was assumed to be a representation of motivational factors that directly influenced behaviour. In other words, the intention was a motivational intention of a person who developed and changed his behaviour according to what he wanted consciously and intentionally. In TPB, Ajzen stated that three independent factors determined intention. The first independent factor was the attitude or attitude to give a positive or negative response based on an assessment of something given. The second factor was the social factor called subjective norm, and this referred to the perceived social pressure to do or not do a given behaviour. The third factor was behavioural control which referred to the ease or difficulty to act. Perceived behavioural control was to reflect on past experience as anticipated obstacles and obstacles. The higher the perceived behavioural control, the stronger the intention of individuals to perform a behaviour.

The stronger the intention, the more individual would tend to carry out specific actions or activities that referred to the behaviour. Ajzen (1991) stated that intention could predict behaviour directly. Dayaratne and Wijethunga (2015) examined the investing intentions of shares in the Colombo Stock Exchange. They found that stock returns and risks influenced the intention to invest.

According to Ajzen (1991), intentions captured motivational factors that influenced behaviour. It was an indication of how hard people wanted to try from how much effort they expended to perform the behaviour. The stronger the intention to engage in a behaviour, the more likely it was that the behaviour would happen. However, it must be clear that the behavioural intention could find expression in the behaviour only if the behaviour was under the control of the will, i.e. if the person could decide to do or not do the behaviour. Although some responses could fulfil these requirements, most depended on some level on non-motivational factors such as the availability of the required opportunities (time, money, skills, etc.). Collectively, these factors represented people's actual control of their behaviour. As long as someone had the opportunities and resources needed and intended to do the behaviour, they would succeed in doing so. Behaviour was the result of a person's intention to do something, whereby the behaviour must be under the control of the will for this to happen. Behaviour under will control is a behavior where people can decide and are willing to be involved or 
not (Ajzen, 1991). Paramita et al. (2018) found that the intention to invest in shares did exist in youth investor.

Finally, attitude, subjective norm and perceived behavioural control, directly affect the formation of individual intentions that will develop into a behavior. We add one variable called product involvement to form considerations for investing. This variable appeared in the exploratory survey as a preliminary study from the employee of IDX. We propose the following hypothesis:

$\mathrm{H} 1$ : Intention has a positive and significant effect on the behaviour of IDX employees to invest in retail bonds.

$\mathrm{H}_{2}$ : Attitude has a significant and positive effect on the intention of IDX employees to invest in retail bonds.

$\mathrm{H}_{3}$ : Subjective norms have a positive and significant effect on the intention of IDX employees to invest in retail bonds.

$\mathrm{H}_{5}$ : Product involvement has a positive effect on the intentions of IDX employees to invest in retails bonds.

H6: Perceived behavioral control has a positive and significant effect on the behaviour of IDX employees to invest in retail bonds.

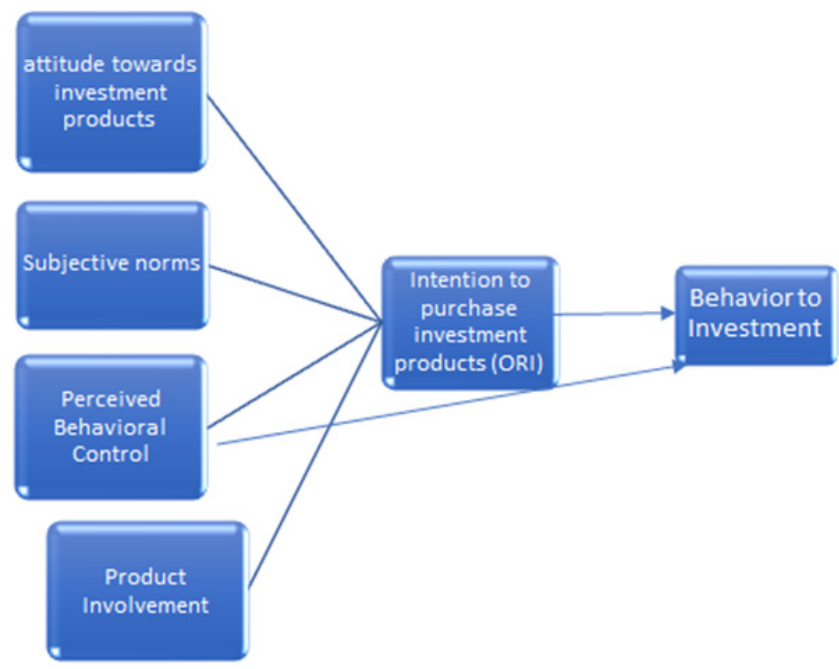

Figure 1. Research Model

\section{Research Method}

The population of 547 respondents in this study were all employees, 547 not including the Board of Commissioners and Directors. The average work period of employees was 9.04 years and the employees aged under 30 years was $38 \%$. The organizational structure had four layers, starting from the bottom: Non-Staff ( 35 people), Staff (398), Unit Heads (82 people), and Division Heads ( 32 people). The majority of IDX employees held bachelor's degrees (64\%), with master's degrees (21.9\%), diploma (6.4\%) and high school (7\%) (Annual Report 2018, 2019).

This study used proportionate stratified random sampling to cover all position levels in the same proportion. We followed Arikunto (2010) to determine the number of samples. Our sample was more than 100 respondents, and used the portion of $10-15 \%$ or $20-25 \%$. We used the proportion of $20 \%$ to determine the sample of each position. 
Table 1. Sampling

\begin{tabular}{|c|l|c|c|}
\hline No & Position & Number of Employees & $\begin{array}{c}\text { Number of Samples } \\
\text { (Proportion = 20\%) }\end{array}$ \\
\hline 1 & Head of Division & 32 & 6 \\
\hline 2 & Unit Head & 82 & 16 \\
\hline 3 & Staff & 398 & 80 \\
\hline 4 & Non Staff & 35 & 7 \\
\hline Total & 547 & 109 \\
\hline
\end{tabular}

Source: Author (2019)

The questionnaire used an electronic form using a Likert scale. A Likert scale measures the attitudes, opinions and perceptions of a person or group of people about social phenomena (Mc Leod, 2019), such as explaining the views or viewpoints of IDX employees towards investment intentions in retail bonds. The Likert was on a scale of 1 to 5 , where 1 was 'strongly disagree' (STS), 2 was 'disagree' (TS), 3 was 'undecided', 4 was agree (S) and 5 was strongly agree (SS). The questionnaire used a crosssectional method, where the data was collected one at a time only. The dependent variable was the intention of IDX employees to invest in retail bonds. The independent variables consisted of attitude, subjective norm, perceived behavioural control and product involvement. The following table explains the variable of mentality.

Table 2: Attitude

\begin{tabular}{|l|l|l|l|}
\hline Variable & Source & Item & Indicator \\
\hline Attitude & Cucinelli et al. (2009); & $\mathrm{AT}_{1}$ & I feel that investing in retails bonds has benefited me. \\
\cline { 3 - 4 } & Gopi \& Ramayah (2007) & $\mathrm{AT}_{2}$ & I feel that investing in retail bonds provides profit for me. \\
\cline { 3 - 4 } & & $\mathrm{AT}_{3}$ & I feel that investing in retail bonds is the right action. \\
\cline { 3 - 4 } & $\mathrm{AT}_{4}$ & I understand the advantages and disadvantages of investing in retail bonds. \\
\cline { 3 - 4 } & $\mathrm{AT}_{5}$ & I feel that the knowledge I have supports me to invest in retail bonds. \\
\hline
\end{tabular}

Subjective norms are the influence of friends, coworkers and family members who have an impact on ORI investment decisions. Three indicators can be applied to measure personal standards: family members, friends and coworkers (Sondari \& Sudarsono, 2009). Subjective norms are expectations felt by others that influence a person to perform certain behaviours (Ajzen, 2005).

Table 3: Variable Subjective Norm

\begin{tabular}{|c|c|c|c|}
\hline Variable & Source & Item & Indicator \\
\hline \multirow[t]{9}{*}{ Subjective norm } & \multirow{9}{*}{$\begin{array}{l}\text { Sondari \& Sudarsono } \\
(2009) ; \\
\text { Alleyne \& Broome } \\
(2011)\end{array}$} & SN1 & My family will suggest me to choose a retail bonds investment. \\
\hline & & $\mathrm{SN}_{2}$ & My friend will suggest me to choose a retail bonds investment. \\
\hline & & $\mathrm{SN}_{3}$ & My coworkers will advise me to choose retail bonds investments. \\
\hline & & $\mathrm{SN}_{4}$ & My family will support my decision to invest in retail bonds. \\
\hline & & $\mathrm{SN}_{5}$ & My friend will support my decision to invest retails bonds. \\
\hline & & SN6 & My coworkers will support my decision to invest ORI. \\
\hline & & $\mathrm{SN}_{7}$ & My family feels that investing in ORI is a good thing. \\
\hline & & SN8 & My friend feels that investing in retail bonds is a good thing. \\
\hline & & SN9 & My coworkers feel retail bonds investing is a right action. \\
\hline
\end{tabular}

Perceived behavioural control is an individual's perception of how easy or difficult it is to manifest a specific behaviour (Ajzen, 2005). Five indicators can be applied to measure perceived behavioural control, as in Table 4. 
Table 4: Variable Perceived Behavioural Control

\begin{tabular}{|l|l|l|l|}
\hline Variable & Source & Item & Indicator \\
\hline $\begin{array}{l}\text { Perceived } \\
\text { behavioural } \\
\text { control }\end{array}$ & $\begin{array}{l}\text { Satsios \& Hadjidakis } \\
(2018) ;\end{array}$ & $\begin{array}{l}\text { Ali, Zani \& Kasim } \\
\text { (2014) }\end{array}$ & I feel it is easy to invest in retails bonds. \\
\cline { 3 - 4 } & & $\mathrm{PB}_{2}$ & I feel the opportunity to invest in retail bonds is wide open. \\
\cline { 2 - 4 } & $\mathrm{PB}_{3}$ & I feel that investing in retail bonds will change several things in my life. \\
\cline { 2 - 4 } & $\mathrm{PB}_{4}$ & I feel I have control over investing in retail bonds. \\
\hline
\end{tabular}

Product involvement is the perception of consumers about the importance of products based on the needs, values, and interests inherent in consumers Zaichkowsky (1985) and Ibrahim and Arshad (2017). The detail is in Table 5 .

Table 5: Variable Product Involvement

\begin{tabular}{|l|l|l|l|}
\hline Variable & Source & Item & Indicator \\
\hline $\begin{array}{l}\text { Product } \\
\text { involvement }\end{array}$ & $\begin{array}{l}\text { Ibrahim \& } \\
\text { Arshad } \\
(2017)\end{array}$ & PA1 & I find retails bonds' coupons or yields are attractive. \\
\cline { 2 - 4 } & & PA2 & I find it easy to get information about retail bonds' product specifications. \\
\cline { 2 - 3 } & PA3 & I find it easy to get information about how to invest in retail bonds. \\
\hline \multirow{5}{*}{} & PA4 & $\begin{array}{l}\text { I find it easy to buy retails bonds through sales agents who have obtained } \\
\text { permission from the government. }\end{array}$ \\
\cline { 2 - 4 } & PA5 & I find purchasing retail bonds is easy. \\
\hline & PA6 & I feel the process of purchasing retail bonds is fast. \\
\hline & PA7 & I find it easy to sell or buy retail bonds in the secondary market. \\
\hline & PA8 & I find the cost in retail bonds is affordable. \\
\hline & PA9 & I find the tenor or horizon matches my investment goals. \\
\hline
\end{tabular}

The intention was to someone's readiness to show a behaviour (Ajzen, 2005). Aiming to invest in retails bonds would show behaviour related to investing in retail bonds in IDX employees.

Table 6: Variable Intention

\begin{tabular}{|l|l|l|l|}
\hline Variable & Source & Item & Indicator \\
\hline Intention & $\begin{array}{l}\text { Ajzen (2015), Satsios \& } \\
\text { Hadjidakis (2018) }\end{array}$ & $\mathrm{IN}_{1}$ & I need to invest. \\
\cline { 2 - 4 } & & $\mathrm{IN}_{2}$ & I need to invest in products that can provide positive returns. \\
\cline { 2 - 4 } & & $\mathrm{IN}_{3}$ & Investment in retail bonds must increase in society. \\
\cline { 3 - 4 } & $\mathrm{IN}_{4}$ & I have the intention to invest in retail bonds. \\
\cline { 2 - 4 } & $\mathrm{IN}_{5}$ & I have a high intention to invest in retail bonds. \\
\hline
\end{tabular}

Behaviour is the result of a person's intention to do something. In this study, the outcome of investing behaviour in retail bonds was the objective. The new behaviour of investing in retails bonds could be a channel from the government to increase the number of buyers. The indicators are in Table 7 .

Table 7: Variable Behaviour

\begin{tabular}{|l|l|l|l|}
\hline Variable & Source & Item & Indicator \\
\hline \multirow{3}{*}{ Behaviour } & $\begin{array}{l}\text { Ajzen (1991), } \\
\text { Paramita et al (2018) }\end{array}$ & $\mathrm{BE} 1$ & I have invested in retail bonds. \\
\cline { 3 - 4 } & & $\mathrm{BE} 2$ & I have other investments. \\
\cline { 2 - 4 } & & $\mathrm{BE} 3$ & I feel satisfied investing in retail bonds. \\
\hline
\end{tabular}

We ensured that the percentage of missing data set per indicator was small (less than $5 \%$ ). We 
deleted the incomplete data. We analyzed the data using structural equation modelling, with path analysis from Smart PLS. The steps, according to Hair et al. (2014) were as follows:

- Structural Model (Inner Model) was the analysis process to define the specification of the structural model. The structural model was a model to describe the relationship between latent variables.

- Measurement Model (Outer Model), was to design the representation of the relationship between the construct and the indicator variables that measured it. The types of measurement models consisted of reflective measurement models and formative measurement models, while constructs were measured with single items and multi-items.

\subsection{Evaluation of Measurement Model}

The measurement model had to meet the requirements of validity and reliability significance. The reflective measurement model was evaluated using composite reliability to assess internal consistency as well as individual indicator reliability, and average variance extracted to assess convergent validity. The discriminant validity used Fornell-Lacker criteria and cross-loading. The requirements are in Table 8.

Table 8: The Specification of the Measurement Model

\begin{tabular}{|c|c|c|}
\hline Attribute & Criteria & Description \\
\hline \multirow{6}{*}{$\begin{array}{l}\text { Reflective } \\
\text { Measurement Model }\end{array}$} & Loading Factor & The loading factor value must be greater than 0.6 \\
\hline & $\begin{array}{l}\text { Average Variance } \\
\text { Extracted (AVE) }\end{array}$ & AVE value must be above 0.5 \\
\hline & Discriminant Validity & $\begin{array}{l}\text { The square root value of AVE must be higher than the correlation } \\
\text { value between latent variables }\end{array}$ \\
\hline & Cross Loading & $\begin{array}{l}\text { Each indicator block should have higher loading for each latent } \\
\text { variable measured compared to the indicator for other latent } \\
\text { variables }\end{array}$ \\
\hline & Composite Reliability & Composite reliability must be above 0.6 \\
\hline & Cronbach's Alpha & Cronbach's alpha value must be above 0.7 \\
\hline
\end{tabular}

\subsection{Evaluation of Structural Models}

The value of R-Square showed the prediction of the structural model to explain the effect of latent (exogenous) variables on latent variables (endogenous). The criteria of R-square used Hair et al. (2014) in Table 9.

Table 9: Specifications of Structural Model

\begin{tabular}{|l|l|}
\hline Criteria & Description \\
\hline $\begin{array}{l}\text { R-Square for latent } \\
\text { endogen variable }\end{array}$ & $\begin{array}{l}\text { R-square results of o.75, o.5, and o.25 for endogenous latent variables in the structural } \\
\text { model indicate that the model is good, moderate, and weak, respectively. }\end{array}$ \\
\hline $\begin{array}{l}\text { Estimated path } \\
\text { coefficient }\end{array}$ & $\begin{array}{l}\text { The estimated value for the path relationship in the structural model must be significant. } \\
\text { The bootstrapping procedure can obtain this significance value. }\end{array}$ \\
\hline
\end{tabular}

The model was estimated using the path coefficient and $R$ square to maximize the variance that could be explained by the dependent variable. The relationship between indicator variables with reflective constructs was an outer loading, while the relationship between indicator variables and formatives was called the external weight. To achieve this, PLS used a bootstrapping method, an algorithm iteration procedure which consisted of two stages: construct score estimation, and an outer weight calculation to produce path coefficient and R-square values. 
Hypothesis testing used p-values to show the significance level. This study applied a standard significance level of alpha $(\alpha)=5 \%$. If the P-value $\leq$ value $\alpha$, we accepted the null hypothesis. If the Pvalue $>$ value $\alpha$, the alternate theory would be accepted. The alternative hypothesis explained that there is no influence of the independent variable on the dependent variable.

\section{Results}

There were 109 respondents, which represented a return ratio of $10 \%$ in 1 month. Below is the descriptive analysis of the characteristics of respondents.

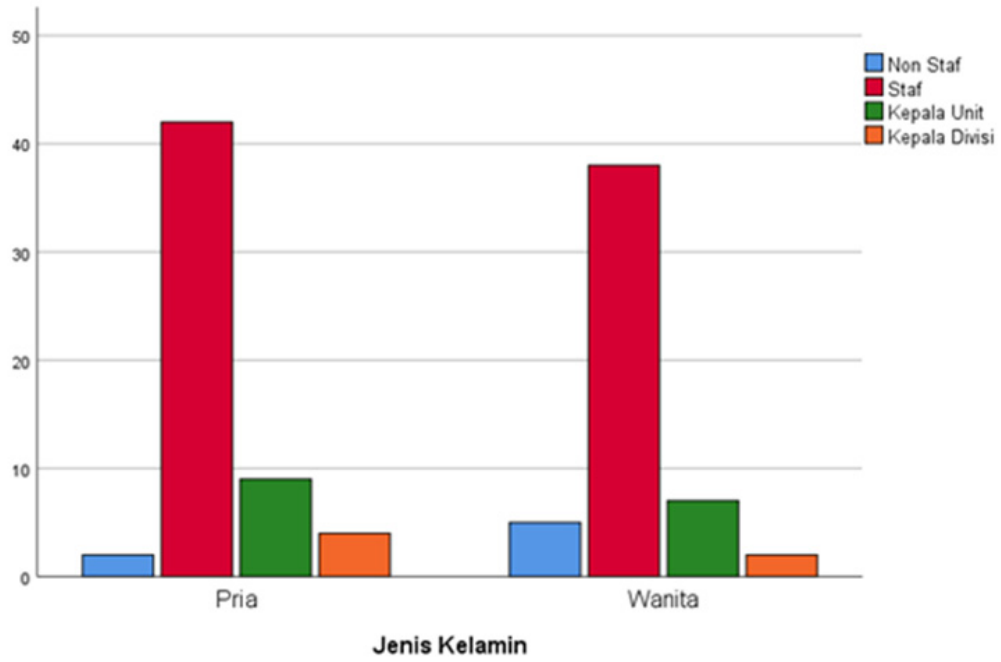

Figure 1. Position Level and Gender

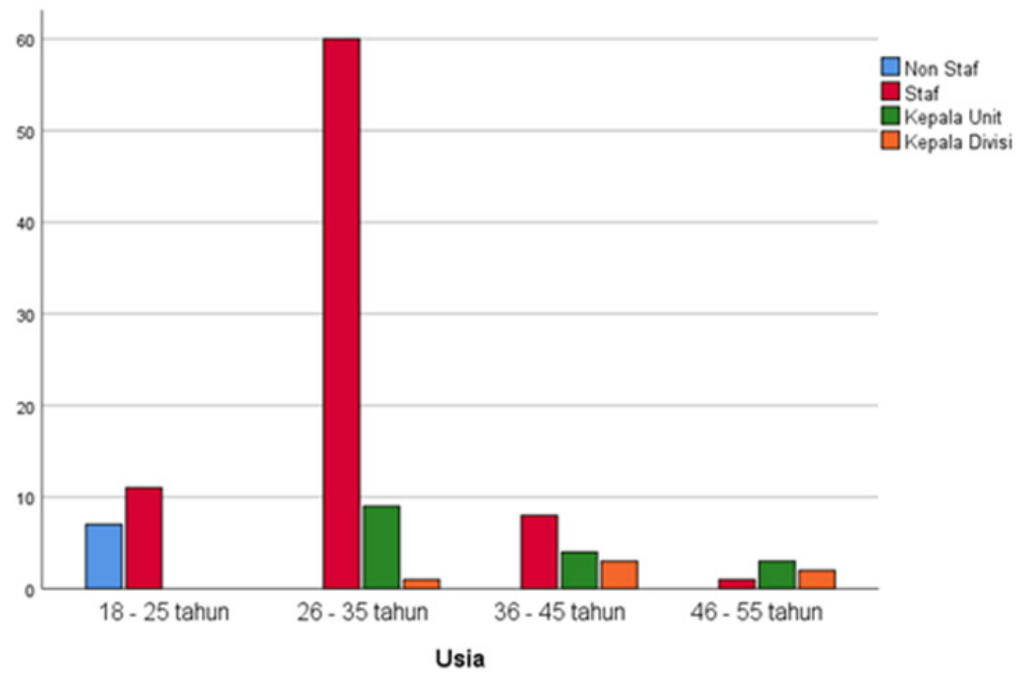

Figure 2. Position Level Based on Age 


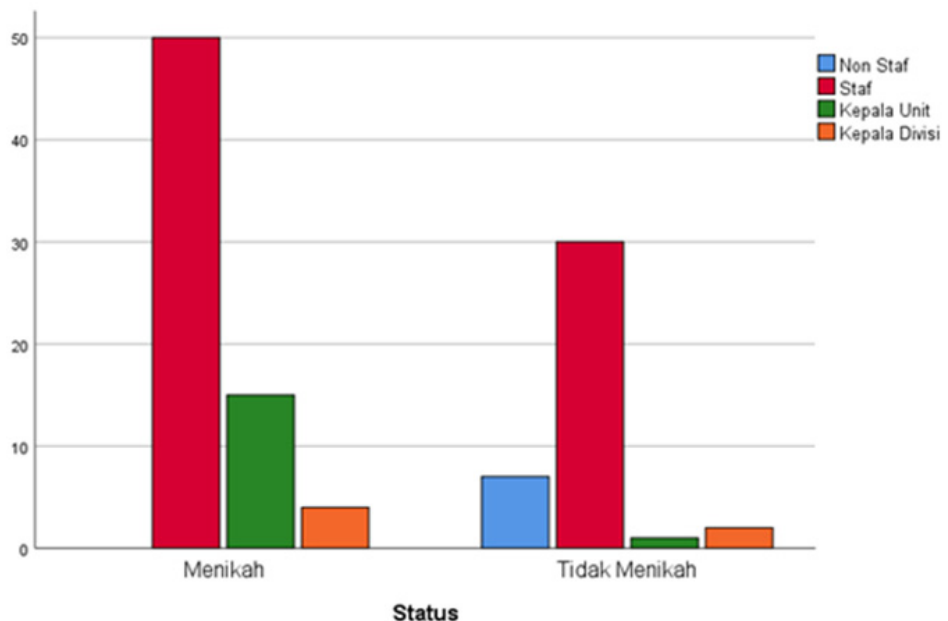

Figure 3. Position Level Based on Marital Status

\subsection{Validity Test}

Table 10 showed all indicators with loading factors greater than o.6. It means the validity score was good - the final model used 32 indicators, instead of 36 as in the original model.

Table 10: Validity Test Results with Loading Factor Parameters

\begin{tabular}{|c|c|c|c|c|c|c|}
\hline & Attitude & Behaviour & Intention & $P B C$ & Product Involvement & Subjective Norm \\
\hline AT1 & 0.877 & & & & & \\
\hline$\overline{A T 2}$ & 0.883 & & & & & \\
\hline $\mathrm{AT}_{3}$ & 0.787 & & & & & \\
\hline $\mathrm{AT}_{4}$ & 0.680 & & & & & \\
\hline $\mathrm{AT}_{5}$ & 0.700 & & & & & \\
\hline BE1 & & 0.941 & & & & \\
\hline $\mathrm{BE}_{2}$ & & 0.634 & & & & \\
\hline$\overline{B E 3}$ & & 0.918 & & & & \\
\hline IN1 & & & 0.653 & & & \\
\hline IN2 & & & 0.661 & & & \\
\hline $\mathrm{IN}_{3}$ & & & 0.858 & & & \\
\hline $\mathrm{IN}_{4}$ & & & 0.887 & & & \\
\hline IN5 & & & 0.859 & & & \\
\hline PA1 & & & & & 0.643 & \\
\hline PA2 & & & & & 0.813 & \\
\hline $\mathrm{PA}_{3}$ & & & & & 0.793 & \\
\hline $\mathrm{PA}_{4}$ & & & & & 0.745 & \\
\hline PA5 & & & & & 0.777 & \\
\hline PA6 & & & & & 0.843 & \\
\hline PA8 & & & & & 0.662 & \\
\hline PA9 & & & & & 0.677 & \\
\hline PB1 & & & & 0.836 & & \\
\hline $\mathbf{P B}_{2}$ & & & & 0.790 & & \\
\hline $\mathrm{PB}_{3}$ & & & & 0.862 & & \\
\hline
\end{tabular}




\begin{tabular}{|c|c|l|l|c|c|c|}
\hline & Attitude & Behaviour & Intention & PBC & Product Involvement & Subjective Norm \\
\hline PB4 $_{4}$ & & & $\mathbf{0 . 7 8 4}$ & & \\
\hline PB5 & & & $\mathbf{0 . 8 0 7}$ & & \\
\hline SN4 $_{4}$ & & & & & $\mathbf{0 . 8 4 5}$ \\
\hline SN5 & & & & & $\mathbf{0 . 9 1 4}$ \\
\hline SN6 & & & & & $\mathbf{0 . 8 8 8}$ \\
\hline SN8 & & & & & & $\mathbf{0 . 8 5 1}$ \\
\hline SN9 & & & & & & $\mathbf{0 . 9 2 2}$ \\
\hline
\end{tabular}

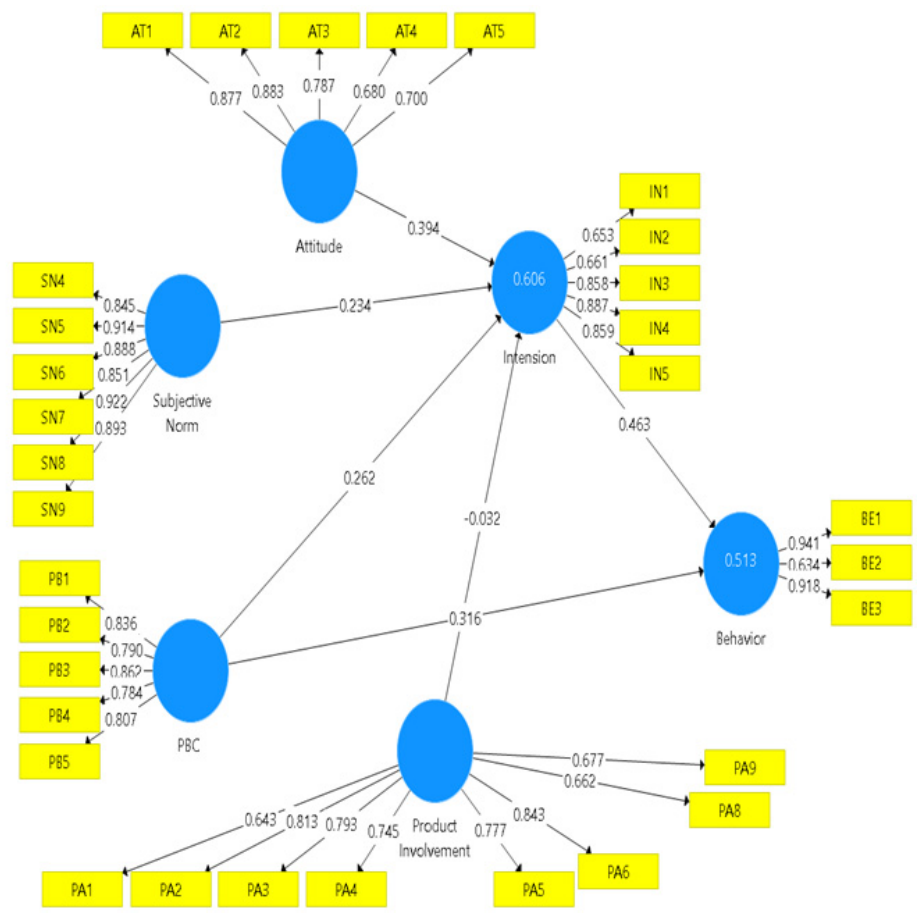

Figure 4. Path Analysis of Behavioral Investment in Retail Bonds

\subsection{Average Variance Extracted (AVE)}

AVE showed the average percentage score of the variance extracted from a set of latent variables estimated by loading the standardize indicator in the iteration process algorithm in PLS. Table 11 declared all AVE values as valid because they were greater than 0.5 .

Table 11: Validity Test Results with Parameters Average Variance Extracted (AVE)

\begin{tabular}{|l|c|c|}
\hline Variable & AVE & Justification \\
\hline Attitude & 0.624 & Valid \\
\hline Behavior & 0.710 & Valid \\
\hline Intention & 0.625 & Valid \\
\hline PBC & 0.666 & Valid \\
\hline Product Involvement & 0.559 & Valid \\
\hline Subjective Norm & 0.785 & Valid \\
\hline
\end{tabular}




\subsection{Discriminant Validity}

The method used to measure the discriminant validity of the measurement model (outer model) was to compare the roots of AVE for each variable with the correlation between variables with other variables in the model. If the root value of AVE was greater than the relationship of other variables, then the variable was said to be valid. Table 4.4 below shows that all latent variables met these criteria. So all latent variables were declared valid.

Table 12: Discriminant Validity

\begin{tabular}{|l|c|c|c|c|c|c|}
\hline & Attitude & Behaviour & Intention & PBC & $\begin{array}{c}\text { Product } \\
\text { Involvement }\end{array}$ & $\begin{array}{c}\text { Subjective } \\
\text { Norm }\end{array}$ \\
\hline Attitude & 0.79 & & & & & \\
\hline Behavior & 0.604 & 0.843 & & & & \\
\hline Intention & 0.724 & 0.678 & 0.79 & & & \\
\hline PBC & 0.692 & 0.631 & 0.682 & 0.816 & & \\
\hline Product Involvement & 0.636 & 0.555 & 0.594 & 0.828 & 0.747 & \\
\hline Subjective Norm & 0.721 & 0.604 & 0.691 & 0.742 & 0.675 & 0.886 \\
\hline
\end{tabular}

\subsection{Cross Loading}

By the criteria in Table 8, the measurement model (outer model) was valid if the loading factor value of each indicator for its latent variable had a higher loading value compared to the loading value of the index for other latent variables. So all indicators were declared valid.

\subsection{Reliability Test}

The reliability test consisted of composite reality and Cronbach's Alpha. The composite reliability indicated the reliability of the questionnaire, while Cronbach's Alpha measured the internal consistency on indicators.

\subsection{Composite Reliability}

Composite reliability is a value that measures the internal consistency of a latent variable. Latent variables were declared reliable if they had a composite value of relativity more than 0.7. Table 13 below shows that all latent variables met the criteria of composite reliability value so all latent variables were declared reliable.

Table 13: Reliability Test Results with Composite Reliability Parameters

\begin{tabular}{|l|c|c|}
\hline Variable & Composite Reliability & Justification \\
\hline Attitude & 0.891 & Reliable \\
\hline Behavior & 0.877 & Reliable \\
\hline Intention & 0.891 & Reliable \\
\hline PBC & 0.909 & Reliable \\
\hline Product Involvement & 0.909 & Reliable \\
\hline Subjective Norm & 0.956 & Reliable \\
\hline
\end{tabular}

\subsection{Cronbach's Alpha}

Cronbach's alpha is a value that measures the internal consistency of a latent variable. Latent variables were declared reliable if they had a Cronbach's alpha value of more than o.6. Table 14 shows 
that all latent variables met the Cronbach's alpha value criteria. So all latent variables were declared reliable.

Table 14: Reliability Test Results with Parameters Cronbach's Alpha

\begin{tabular}{|l|c|c|}
\hline Variable & Cronbach's Alpha & Justification \\
\hline Attitude & 0.851 & Reliable \\
\hline Behavior & 0.782 & Reliable \\
\hline Intention & 0.858 & Reliable \\
\hline PBC & 0.875 & Reliable \\
\hline Product Involvement & 0.888 & Reliable \\
\hline Subjective Norm & 0.945 & Reliable \\
\hline
\end{tabular}

\subsection{Structural Model Testing}

\subsection{Path Coefficient}

Path Coefficient was used to check the significance of the relationship between the latent variables and the bootstrapping process that produced an at-statistic value (the Smart PLS program provided a $\mathrm{p}$-value). The t-statistic value was compared with the t-table. If the t-statistic amount was more significant than the t-table (or p-value $\leq \alpha$ ), then the related variable was stated to have had a substantial effect. For a confidence level of $95 \%(\alpha=5 \%)$, the t-table was 1.96. A positive value on the path coefficient indicated that the related variable had a positive effect; on the contrary, if the value of the path coefficient was negative, then the associated variable had a negative impact.

Table 15: The Results of the Path Coefficient Model Using Bootstrapping

\begin{tabular}{|l|c|c|c|c|}
\hline & Path Coefficient & T Table & T Statistics & P Values \\
\hline Attitude $\rightarrow$ Intention & 0.394 & 0.107 & 3.678 & 0.0001 \\
\hline Intention $\rightarrow$ Behavior & 0.463 & 0.106 & 4.372 & 0.00000000000006 \\
\hline PBC $\rightarrow$ Intention & 0.262 & 0.147 & 1.779 & 0.076 \\
\hline Product Involvement $\rightarrow$ Intention & -0.032 & 0.141 & 0.228 & 0.820 \\
\hline Subjective Norm $\rightarrow$ Intention & 0.234 & 0.096 & 2.431 & 0.015 \\
\hline$P B C \rightarrow$ Behavior & 0.316 & 0.102 & 3.093 & 0.002 \\
\hline
\end{tabular}

\subsubsection{R-Square}

Table 16 shows the R-Square values for two dependent variables. The coefficient of determination was to indicate how much influence the influencing variable had on the affected variable. The R-Square value equation was intention $=(0.394$ * attitude $)+(0.262$ * $\mathrm{pbc})-(\mathrm{o.032}$ * product involvement $)+(0.234$ * subjective norm) + error. The R-Square 0.591 showed that changes in attitude could explain $59.1 \%$ of the variables 'intention', 'perceived behavioral control' (PBC), 'product involvement' and 'subjective norm' variables. In comparison, the remaining $40.9 \%$ is due to other factors outside the model.

The R-Square value of the behavior equation $=(0.463$ * intention $)+(0.316$ * PBC $)+$ error. The RSquare above 0.504 showed that $50.4 \%$ of the behavior variance could be explained by changes in the intention and PBC variables, while $49.6 \%$ were caused by other factors outside the model.

Table 16: R-square Value on Behaviour and Intention Variables

\begin{tabular}{|c|c|}
\hline Variable & R-Square \\
\hline Behaviour & 0.504 \\
\hline Intention & 0.591 \\
\hline & 199 \\
\hline
\end{tabular}




\subsection{Hypothesis Testing}

The central hypothesis in this study was to find out whether the intention of IDX employees to invest in ORI products had a positive and significant effect on decisions in buying ORI investment products. Table 17 shows the path coefficient had a p-value below 0.05. We concluded that the intention of IDX employees to invest in ORI products had a positive and significant effect on decisions in investing in ORI, which meant the alternate hypothesis was accepted.

Table 17: Hypothesis Testing Result

\begin{tabular}{|c|c|c|c|c|c|}
\hline Hypothesis & Variable & Significance level & Path Coefficient & P-value & Result \\
\hline $\mathrm{H}_{\mathrm{o}}$ & Intention $\rightarrow$ Behavior & Not significant & & Reject \\
\hline $\mathrm{H}_{1}$ & Intention $\rightarrow$ Behavior & Positive Significant & 0.463 & 0.00000000000006 & Accept \\
\hline
\end{tabular}

Table 18 shows the summary of supporting hypothesis.

Table 18: Supporting Hypothesis

\begin{tabular}{|c|l|l|c|c|c|}
\hline Hypothesis & Variables & Significance level & Path Coefficient & P-value & Result \\
\hline $\mathrm{H}_{2}$ & attitude $\rightarrow$ Intention & Positive Significant & 0.394 & o.0oo1 & Accept \\
\hline $\mathrm{H}_{3}$ & Subjective Norm $\rightarrow$ Intention & Positive Significant & 0.234 & o.o15 & Accept \\
\hline $\mathrm{H}_{4}$ & PBC $\rightarrow$ Intention & Not significant & 0.262 & o.076 & Reject \\
\hline $\mathrm{H}_{5}$ & Product Involvement $\rightarrow$ Intention & Not significant & -0.032 & o.820 & Reject \\
\hline $\mathrm{H}_{6}$ & PBC $\rightarrow$ Behaviour & Positive Significant & 0.316 & o.002 & Accept \\
\hline
\end{tabular}

4.11 Discussion

From the six tested hypotheses, four hypotheses were accepted, and two hypotheses were rejected (not including Ho). It meant that not all factors proposed in this study affected the investment behaviour decisions of retail bonds by employees. The intention variable R-square value of 0.591 showed that $59.1 \%$ of the intention variance could be explained by changes in the attitude, perceived behavioural control, product involvement and subjective norm variables, while other factors outside the model caused the additional $40.9 \%$. Also, the analysis showed that the intention to invest employees in retail bonds products had a significant and positive effect on ORI investment decisions by employees. The R-square value of the behaviour of 0.504 indicated that $50.4 \%$ of the behaviour variance can be explained by changes in the intention and perceived behavioural control variables, while other factors outside the model caused the additional 49.6\%. A detailed explanation of the effect of the independent variables on the dependent variable produced in this study is as follows:

\subsubsection{The Effect of Attitude on the Intention of Employees to Invest in Retail Bonds Products}

Based on the questionnaire filled out by respondents, all questions on the attitude variable on the survey were declared valid, and the results on processing illustrated those attitude variables had a significant and positive influence on the investment intentions of employees on retail bond products. The results of the data processing showed that potential investors from the employees were more likely to choose to invest in retail bonds because they believed investing retail bonds was the right action and provided benefits and benefits. Also, employees tended to feel that the knowledge they had about the capital market could help them understand the advantages and disadvantages of investing in retail bonds so that it drove their intention to invest. The background knowledge of the employees was obtained not only from daily work but also from the education they attained when they first started working at the company. During the education period, there were taught many 
fundamentals about the capital market, one of which was regarding fixed income investment products, including retail bond products.

The results of this study were also in line with previous studies conducted by Cucinelli et al. (2016). They found that attitude had a positive impact and was one of the most significant for intention in applying for financial products in Italy. The results of this study also had the same results with research conducted by Gopi and Ramayah (2007) who found that attitude was a significant factor influencing the intention to invest in online shares in Malaysia. A study conducted by Sondari and Sudarsono (2015) used the Theory of Planned Behavior to predict the investment objectives of civil servants in Indonesia, and showed the variable attitudes of employees towardss investment had a significant impact on investment intentions of civil servants in Indonesia.

The value of the results of data processing in the form of p-value 0.0001 showed that $\mathrm{H}_{2}$ hypothesis was accepted, so the attitude variable was proven to have a positive and significant influence on the investment intentions of employees in retail bond products. We found that the attitude variable generally had a positive and significant impact on investment intentions for financial products.

\subsubsection{The Influence of Subjective Norms on the Intentions of Employees to Invest in Retail Bond Products}

In the questionnaire filled out by respondents, not all questions on the subjective norms variable in the survey were declared valid. Due to problems with the subjective norm variables, which initially consisted of nine questions, these became six questions. Based on the validity test of the first questionnaire, three questions were invalid because they did not meet the loading factor criteria. These three questions were questions that related to the advice of family, coworkers or friends who provided advice on choosing ORI investments. After the invalid indicators were deleted, six items whose values met the loading factor criteria were used for further validity tests, and the results of these six questions matched the value of the loading factor criteria for further testing.

The final result of data processing showed that subjective norms also have a positive and significant effect on the intention to invest employees in retail bond products. Potential investors from the employees were more likely to choose to invest in retail bonds because of the excellent views and support for retail bond investments from colleagues, family and friends.

The results of this study were in line with previous research conducted by Sondari and Sudarsono (2015) which showed that attitudes towards investment and subjective norms had a significant influence on the intention to invest among civil servants in Indonesia. In addition to the research conducted by Sondari and Sudarsono, research conducted by Alleyne and Broome (2011), Cucinelli et al. (2016) and Gopi and Ramayah (2007) found that in addition to attitude variables, subjective norms variables were factors that influenced investment intentions significantly.

The value of the results of data processing in the form of p-value of 0.015 showed that the $\mathrm{H}_{3}$ hypothesis was accepted, that is, the subjective norms variable proved to have a positive and significant influence on the investment intentions of employees in ORI products. It is in line with Ajzen (2005), and subjective norm proved to influence people's behaviour in choosing retail bonds.

\subsubsection{The Effect of Perceived Behavioural Control on the Intentions of Employees to Invest in Retail Bond Products}

For the perceived behavioural control variable, all questions on the questionnaire were valid for data processing. However, from the results of the final data processing, based on the p-value of 0.076 , this variable was stated not to affect the intention of employees to invest in ORI products. Based on this, $\mathrm{H}_{4}$ was declared rejected.

Based on previous research, the rejection of the hypothesis of the influence between perceived behavioural control on intention also appears in the results of Octarina, Hartoyo and Beik (2019) 
which showed that attitude and subjective norm had a positive and significant effect. Still, the perceived behavioural control variable did not affect the intention to invest in Sharia mutual funds products in Indonesia. In the research conducted by Octarina et al., although potential investors already knew the general picture of sharia mutual fund products, it did not affect their intention to buy them. It was also evident in the results of this study which showed that employees as prospective investors, even though they felt that the opportunity to invest retails bonds was wide open and would provide convenience and financial assistance if they did so, but did not affect their intention to invest in retail bonds.

\subsubsection{The Effect of Product Involvement on the Intention of Employees to Invest in Retail Bond Products}

Product involvement was a novel inclusion for this study. A high coupon bond would attract more subscriptions and buyers. Also, the use of this variable strengthened from the results of interviews in exploratory surveys with several employees reporting that some factors that attracted their intention to invest in retail bonds included coupons, product tenure and ease of purchase. This result was in line with Zaichkowsky (1985) as consumers' perceptions of the importance of products was based on the needs, values, and interests inherent in consumers.

The use of product involvement variables in this study was also based on previous research by Ibrahim and Arshad (2017) which showed a significant relationship between product involvement and stock investment intentions by individual investors in Pakistan. Based on their research, product involvement allowed investors to get more information about stocks so that it would have a positive impact on their intention to invest in Pakistan.

In this study, of the nine questions in the questionnaire related to product involvement variables, only eight items were declared valid because they met the loading factor criteria. Based on the results of the final data processing using eight indicators from the questionnaire, a p-value of o.820 was obtained. The product involvement variable was stated not to influence the intention of employees to invest in retail bond products. Based on this, $\mathrm{H}_{5}$ was rejected.

The results of this research that contrasted with previous studies showed that coupons, tenors, and ease of buying retail bonds did not necessarily influence the intention of employees to invest. In Listyarti and Suryani (2014), the perceived behavioural control influenced the intention of selecting the stock, which was in line with this study. The use of funds derived from their funds also made for a consideration in investing.

\subsubsection{The Effect of Perceived Behavioural Control on the Behaviour of Employees to Invest in Retail Bonds}

The results of this study were in line with the TPB theory proposed by Ajzen (1991), where perceived behavioural control, together with intention, can be used directly to predict behaviour. The TPB theory proposed there was a significant and positive relationship between perceived behavioural control and behaviour. Based on a questionnaire filled out by respondents, if respondents felt the ease and benefits it would significantly increase their tendency to buy and invest in ORI. The value of the results of data processing in the form of a p-value of 0.002 showed that the hypothesis H6 was accepted, that is, the perceived behavioural control variable had a positive and significant effect on the investment behaviour of employees in retail bonds products. It was found that the observed behavioural control variable was a variable that generally had a positive and significant influence on investment behaviour on financial products.

\subsubsection{The Influence of Intention on the Behaviour of Employees to Invest in Retail Bonds}

In the questionnaire, all questions qualified in the test. Based on the results the intention to invest in retail bonds had a significant and positive effect on retail bond investment decisions by employees. The R-square value of 0.591 indicated that $59.1 \%$ of the behavior variance can be explained by changes 
in the intention variable, while other factors outside the model caused the additional $40.9 \%$. Based on this, H1 was declared accepted, and Ho rejected.

The results of this study were in line with the results of a previous study by Paramita et al. (2018). They used TPB to examine the behaviour of young Surabaya investors in investing in stocks which found that although the variables in TPB did not influence investing behaviour, a positive effect was found between intentions on the behaviour of spending among young investors in stock products. The results also showed that Ajzen (1991) explained that the more influential the intention to engage in response, the more likely the realization of the behaviour could apply to the investment behaviour of employees in retail bonds.

\section{Conclusion and Implications}

This study investigates the relationship between behaviour and intention in investing in retail bonds. The conclusion is from the six hypotheses in this study, four hypotheses were declared acceptable. The four predictions were significant and showed a positive influence between attitude and subjective norm variables on employees' intention to invest in ORI. There was a substantial and positive influence on the intention and perceived behavioural control variables on employees' behaviour to invest in retail bonds. The two hypotheses were rejected because they were not proven to influence the intentions of employees to invest in ORI. These were the perceived behavioural control and product involvement variables.

This study also provided an overview of the indicators of variables that could significantly and positively increase the intention of employees to invest in retails bonds. Based on the study of attitude variables on investment intentions, potential investors from employees were more likely to choose to invest in retail bond products because they believed that investing in retail bonds was a 'right' action and provided benefits and benefits. Also, employees tended to feel that the knowledge they had about the capital market could make them understand the advantages and disadvantages of investing in retail bonds so it drove their intention to invest. Whereas, from the subjective norm variable, the information obtained by potential investors from employees that was more likely to choose to invest in retails bonds products was because of the excellent views and support for retail bonds investments from colleagues, family and friends. Based on the results, the subjective norm affected investment intentions, as opinions and support for retail bond investment from coworkers, families, and friends had a positive and significant influence on employee intentions to invest in retail bonds.

The Theory of Planned Behaviour (Ajzen, 1991) explained that perceived behavioural control together with intention could be used directly to predict behaviour. The respondents needed to feel ease and benefits to increase their tendency to buy and invest in retail bonds. Therefore, the perceived behavioural control variable was a variable that provided a positive and significant influence on investment behaviour on financial products. The intention to invest employees in bond products also proved to have a substantial and positive effect on retail bond investment decisions by employees so that the more influential the intensity, the more the employees would intend to buy retail bonds as their portfolio investment.

Future research could examine further about product involvement, the risk appetite of investors or employees to create retail bond products that match with the needs of the customers. Furthermore, a longitudinal study could reveal new insights and findings of the investment behaviour of employees. Expanding research not only on retail bonds, but other investment instruments such as mutual fund products, deposits, and other investment products to better understand the intentions and investment behaviour of employees could prove beneficial.

There are critical managerial implications from this study:

1) Management should improve the approach of knowledge of retail bonds through seminars or training. This awareness is essential for employees to pick retail bonds compared to other investment products. 
2) Provide the first opportunity for employees to book or apply for the new and upcoming retail bonds series before the offer period arrives. It can increase the attitude and product involvement towards the intention to invest. It will not only benefit employees but also support the retail bonds selling. Selling online can also be an option.

3) Hold a peer sharing session from employees who already invested in retails bonds to others who did not. This word of mouth method can influence others and be perceived as a subjective norm. It is in line with the results of this study that personal criteria have a positive and significant effect on intentions to purchase investment products, and towards behaviour of investment in retail bonds.

\section{References}

Ajzen, I. (1991). The Theory of Planned Behaviour: Organizational Behaviour and Human Decision Processes, Volume 50, 179-211. Retrieved from https://doi.org/10.1016/0749-5978(91)90020-T.

Ajzen, I. (2005). Attitudes, Personality and Behavior. New York: Open University Press.

Ajzen, I. (2015). Consumer attitudes and Behavior: The Theory of Planned Behavior Applied to Food Consumption Decisions. Rivista di Economia Agraria, 7o(2), 121-138. Retrieved from http://dx.doi.org/10.13128/REA-18003.

Ajzen, I., \& Fishbein, M. (1980). Understanding attitudes and Predicting Social Behavior. Englewood Cliffs, NJ: Prentice-Hall.

Alleyne, P. \& Broome, T. (2011). Using the Theory of Planned Behaviour and Risk Propensity to Measure Investment Intentions among Future Investors. Journal of Eastern Caribbean Studies; Vol. 36, Issue 1, 1-20. Retrieved from https://www.researchgate.net/publication/299483632_Using_the_theory_of_planned_behaviour_and_risk_ propensity_to_measure_investment_intentions_among_future_investors.

Ali, S., Zani, R.M., \& Kasim, K. (2014). Factors Influencing Investors Behavior in Islamic Unit Trust: An Application of Theory of Planned Behavior. Journal of Islamic Economics, Banking \& Finance, 10(2), 183-201. Retrieved from https://pdfs.semanticscholar.org/ac9f/oae2fafd13635b28cccff8aba99be7cf357e.pdf.

Arikunto. (2010). Prosedur Penelitian Suatu Pendekatan Praktek. Jakarta: PT Rineka Cipta.

Bursa Efek Indonesia. (2019). Annual Report, 2018. Retrieved from http://www.idx.co.id/tentang-bei/laporantahunan/.

Bursa Efek Indonesia. (2019). Indonesia Bond Market September 2019. Jakarta: Divisi Pengaturan dan Operasional Perdagangan PT Bursa Efek Indonesia.

Bursa Efek Indonesia. (2019). Indonesia's Economic and Capital Market Development Juli 2019. Jakarta: Divisi Riset PT Bursa Efek Indonesia.

Bursa Efek Indonesia. (2019). Mengenalkan Pasar Modal ke Masyarakat. Retrieved from http://sekolahpasarmodal.idx.co.id/.

Bursa Efek Indonesia. (2019). Pedoman Perilaku Karyawan PT Bursa Efek Indonesia Versi 2. Jakarta: PT Bursa Efek Indonesia.

Bursa Efek Indonesia. (2019). Struktur Organisasi PT Bursa Efek Indonesia. Retrieved from http://www.idx.co.id/tentang-bei/organisasi/ (diakses tanggal 18 Oktober 2019).

Brigham \& Houston. (2006). Fundamentals of Financial Manajement. Jakarta: Salemba Empat.

Cucinelli, D., Gandolfi, G. \& Soana, M. (2016). Customer and Advisor Financial Decisions: The Theory of Planned Behavior Perspective. International Journal of Business and Social Science, Vol 7 No 12 December 2016. Retrieved from https://pdfs.semanticscholar.org/75c9/b84c3e8fi49e833ofo16abafaa356cca2fdo.pdf.

Dayaratne, D.A.I., Wijethunga, AWGCN (2015). Impact of Psychology on Behavioral Intention in Investing in Capital Markets: A survey of Colombo Stock Exchange. International Journal of Accounting \& Business Finance. Issue 2, 3745, 2015. Retrieved from http://www.maco.jfn.ac.lk/ijabf/wp-content/uploads/2017/11/Vol__Issue2_4.pdf

Direktorat Jenderal Pengelolaan Pembiayaan Dan Risiko. (2018). Hasil Penjatahan Obligasi Negara Ritel (ORI). Retrieved from https://www.djppr.kemenkeu.go.id/page/load/228o (diakses tanggal 30 Desember 2019).

Direktorat Jenderal Pengelolaan Pembiayaan Dan Risiko. (2019). Memahami Utang. Retrieved from https://www.djppr.kemenkeu.go.id/pahamiutang/index.php (diakses tanggal 21 Oktober 2019).

Durianto, D., Sugiarto, \& Sitinjak, T. (2004). Strategi Menaklukkan Pasar Melalui Riset Ekuitas dan Perilaku Merek. Jakarta: PT Gramedia Pustaka Utama.

Fahmi, Irham. (2013). Rahasia Saham dan Obligasi. Bandung: Alfabeta. 
Ghozali, Imam. (2011). Structural Equation Modeling: Metode Alternatif dengan Partial Least Square (PLS) Edisi 3. Semarang: Badan Penerbit Universitas Diponegoro.

Gopi, A., \& Ramayah, T. (2007). Applicability of Theory of Planned Behavior in Predicting Intention to Trade Online: Some Evidence from a Developing Country. International Journal of Emerging Markets, Vol. 2 No. 4, 348-36o. Retrieved from https://www.emerald.com/insight/content/doi/10.1108/17468800710824509/full/html.

Hair, J., Hault, G., Ringle, C., \& Sarstedt, M. (2014). A Primer On Partial Least Structural Equations Modeling (PLSSEM). Sage: United States of America.

Ibrahim, Y., \& Arshad, I. (2017). Examining the Impact of Product Involvement, Subjective Norm and Perceived Behavioral Control on Investment Intentions of Individual Investor in Pakistan. Investment Management and Financial Innovations, Volume 14, Issue 4, 2017, 181-193. Retrieved from http://dx.doi.org/10.21511/imfi.14(4).2017.15.

Keown, Arthur J., John D. M., Petty J. W., \& Scott Jr. D. F. (2011). Manajemen Keuangan: Prinsip dan Penerapan. Jilid Satu. Edisi Kesepuluh. Jakarta: PT Indeks.

Kotler, P., \& Armstrong, G. (2014). Principles of Marketing, $15^{\text {th }}$ Edition. Pearson Education Limited.

Kwon, K.-N., Lee, M.-H., \& Jin Kwon, Y. (2008). The Effect of Perceived Product Characteristics on Private Brand Purchases. Journal of Consumer Marketing, 25(2), 105-114. Retrieved from https://doi.org/10.1108/07363760810858846.

Listyarti, I., \& Suryani, T. (2014). Determinant Factors of Investors Behavior in Investment Decision in Indonesian Capital Markets. Journal of Economics, Business, and Accountancy Ventura Vol. 17, No. 1, April 2014,45 - 54. Retrieved from https://journal.perbanas.ac.id/index.php/jebav /article/view/265/208

McLeod, S. A. (2019). Likert scale. Simply Psychology. https://www.simplypsychology.org/likert-scale.html

Paramita, Sista. RA. et al. (2018). Young Investor Behavior: Implementation Theory of Planned Behavior. International Journal of Civil Engineering and Technology (IJCIET) Volume 9, Issue 7, July 2018, 733-746. Retrieved from https://www.researchgate.net/publication/327335452_Young_investor_behavior_implementation_theory_of_plan ned_behavior.

Sekaran, Uma. 2006. Metode Penelitian untuk Bisnis Edisi 4 Buku 1. Jakarta: Salemba Empat.

Satsios, N., \& Hadjidakis, S. (2018). Applying the Theory of Planned Behaviour (TPB) in Saving Behaviour of Pomak Households. International Journal of Financial Research Vol. 9, No. 2, 2018, 122-133. Retrieved from https://doi.org/10.5430/ijfr.v9n2p122.

Singarimbun, M. (2006). Metodologi Penelitian Survai. Jakarta: Pustaka Media.

Sondari, M. C., \& Sudarsono, R. (2015). Using the Theory of Planned Behavior in Predicting Intention to Invest: Case of Indonesia. International Academic Research Journal of Business and Technology 1(2) 2015, $137-141$. Retrieved from http://www.iarjournal.com/wp-content/uploads/IBTC2015-p137-141.pdf.

Sugiyono. (2014). Metode Penelitian Kuantitatif, Kualitatif dan RED. Bandung: Penerbit Alfabeta.

Tjiptono, F. (2008). Strategi Pemasaran Edisi Ketiga. Yogyakarta: Penerbit Andi.

Octarina, E., Hartoyo, \& Beik, I., S. (2019). Customer Purchase Intention on Sharia Mutual Fund Products: A TPB Approach. Journal of Consumer Sciences 2019, Vol. 04, No. 01, 37-47. Retrieved from http://journal.ipb.ac.id/index.php/jcs/article/view/25409.

Zaichkowsky, J.L. (1986). Conceptualizing involvement. Journal of Advertising, 15(2), 4-14, 34, June 1986. Retrieved from https://www.researchgate.net/publication/232576403_Conceptualizing_Involvement 